\title{
CARDIAC MYXOMA IN A DOG
}

Metka Šimundić ${ }^{1}$, Aleksandra Domanjko Petrič², Darja Pavlin², Tadej Zemljič̌ , Igor Firm, Mitja Gombač5 Špela Srečnik Mateja Stojov ${ }^{6}$, Laura Šimenc ${ }^{6}$, Tanja Švara ${ }^{5 *}$

${ }^{1}$ PRVA-K, Small Animal Clinic, Gorkičeva 6, ${ }^{2}$ Small Animal Clinic, Veterinary Faculty, University of Ljubljana, Cestav Mestni log 47, ${ }^{3}$ Veterinarske storitve s.p., Milčinskega ul. 62, 1000 Ljubljana, ${ }^{4}$ Firm Veterinarska Interna medicina, Igor Firm s.p., Nove Loke 35, 3330 Mozirje, ${ }^{5}$ Institute of Pathology, Wild Animals, Fish and Bees, ${ }^{6}$ Student of Veterinary Faculty, Veterinary Faculty, University of Ljubljana, Gerbičeva 60,1000 Ljubljana, Slovenia

*Corresponding author, E-mail: tanja.svara@vf.uni-lj.si

\begin{abstract}
Cardiac tumours occurvery rarely in domesticated animals and humans. The most common cardiac tumours in dogs are hemangiosarcoma and chemodectoma. Myxoma, on the other hand, occurs extremely rarely. In this report, we presenta case of an 11-year-old, spayed, mixed-breed dog with a myxoma arising from the tricuspid valve. The dog presented with syncope, tachypnea, tachycardia, exercise intolerance and progressive ascites. Two-dimensional echocardiography showed a polypoid intracavitarymass in the rightheart. Atnecropsy, a polypoid, red mass was observed arising fromthe tricuspidvalve. Histologically, the mass was composed of spindle-shaped and stellate cells with small hyperchromatic nuclei surrounded with myxoid matrix. After performing immunohistochemistry, the neoplastic cells were found to be strongly positive for vimentin. Based on gross, microscopic, and immunohistochemical staining features, the neoplasm was diagnosed as a cardiac myxoma.
\end{abstract}

Key words: myxoma; heart; dog; two-dimensional echocardiography; histopathology; immunohistochemistry

\section{Introduction}

Cardiac tumours occur very rarely in dogs and humans, with a reported prevalence of $0.19 \%$ in both species $(1,2)$. The most common cardiac tumours in dogs are hemangiosarcoma and tumours of the aortic arch body (chemodectoma and paraganglioma) $(3,4,5)$. In addition, lymphoma (6) and ectopic thyroid carcinoma (7) are also frequently reported. Other cardiac tumours like myxoma (8, $9,10,11,12,13,14)$, mast cell tumour (4), leio-

Received: 19December 2018

Accepted for publication: 29 July 2019 myoma (15) and leiomyosarcoma (16), fibroma (17), fibrosarcoma (18), rhabdomyoma (19), rhabdomyosarcoma (20), melanoma (4), thyroid adenoma (7), myxosarcoma (21), osteosarcoma (22), peripheral nerve sheath tumour (23) and malignant mesenchymoma (24) have been rarely reported.

The World Health Organization (WHO) defines a cardiac myxoma as a neoplasm composed of stellate to plump cytologically bland mesenchymal cells set in a myxoid stroma (25). Although this benign tumour is the most frequent primary cardiac tumour in humans and accounts for $50 \%$ of all cardiac tumours (26). It is, however, rarely reported in dogs. 
The purpose of this report is to comprehensively describe a case of a dog with cardiac myxoma affecting the tricuspid valve. History, clinical presentation, haematology and biochemistry, ultrasound, as the results of necropsy, histopathology and immunohistochemistry are presented.

\section{Case presentation}

An 11-year old, mixed-breed, spayed female dog weighing $8 \mathrm{~kg}$ was presented for evaluation due to a single episode of syncope that happened after exercise 14 days prior to admission. After that episode, the dog became lethargic and exercise intolerant.

Physical, routine haematological and biochemical examinations and two-dimensional echocardiography were performed. On physical examination, tachypnea (44 breaths/min) and tachycardia (164 beats/min) were detected. A systolic diastolic murmur, grade IV/VI, was heard over the tricuspid valve. The dog presented with a moderately distended abdomen. Routine haematological examination showed increased haematocrit $(61 \%$, reference range $37-55 \%)$, polycythemia $\left(10.10 \times 10^{12} / 1\right.$, reference range 5.50 $\left.8.50 \times 10^{12} / 1\right)$ and increased haemoglobin $(19.4 \mathrm{~g} /$ $\mathrm{dl}$, reference range 12.0-18.0 g/dl). Furthermore, slightly elevated serum alanine aminotransferase activity (ALT) (108 U/1, reference range 10-100 $\mathrm{U} / \mathrm{L}$ ) was detected.

A homogenous isoechogenic intracavitary mass in the right ventricle and atrium was observed with two-dimensional echocardiography (Figure 1a). Abdominal ultrasonography demonstrated liver congestion and free abdominal fluid. Fluid was obtained with aspiration and was characterized as modified transudate.

Based on the results of the physical examination, blood work and ultrasonography findings, intracavitary neoplasm in the right portion of the heart with right heart decompensation was suspected.

The owner declined any further diagnostics and therapy, and the dog was euthanized 14 days later due to progression of ascites and respiratory distress.

Necropsy was done at the Institute of Pathology, Wild Animals, Fish and Bees at Veterinary Faculty University of Ljubljana. At the necropsy, a dark red, polypoid, soft elastic mass measuring $3 \times 2.5 \times 1.5$ $\mathrm{cm}$ was found arising from the parietal cusp of the tricuspid valve (Figure 1b). The right atrium and ventricle were severely dilated. The liver, kidneys, spleen and lungs were severely congested, and the lungs was severely oedematous. The abdominal cavity contained one litre of modified transudate.

Samples of the mass were fixed in 10\% buffered formalin and routinely embedded in paraffin for histopathological examination. Tissue sections, each 4- $\mu \mathrm{m}$ thick, were first deparaffinised and then stained with haematoxylin and eosin (HE), toluidine blue and periodic acid-Schiff (PAS). Stained sections were then examined under a light microscope. In addition, immunohistochemistry was conducted on the samples to confirm the mesenchymal origin of the neoplastic cells. Immunohistochemical staining was performed on the 4- $\mu \mathrm{m}$ sections of formalin-fixed, paraffinembedded tissue samples. A mouse monoclonal antibody raised against human vimentin (clone VD9; Dako, Glostrup, Denmark), diluted 1:100, was used for immunolabelling. Antigen retrieval was performed by microwave treatment at medium power $(550 \mathrm{~W})$ for 20 minutes in 0.1 $\mathrm{M}$ citrate buffer ( $\mathrm{pH}$ 6.0). The sections were incubated with primary antibodies for one hour at room temperature in a humid chamber. Endogenous peroxidase activity was quenched with Peroxidase-Blocking Solution, Dako REALTM (DAKO) for 30 minutes at room temperature. Afterwards, the visualization kit DAKO REAL ${ }^{\mathrm{TM}}$ EnVision $^{\mathrm{TM}}$ Detection System Peroxidase/DAB+, Rabbit/Mouse (DAKO) was applied according to the manufacturer's instructions. Sections were counterstained with Mayer's haematoxylin and mounted. Sections of normal canine skin were used as positive controls. Sections treated without primary antibodies served as negative controls.

Upon microscopic examination, the cardiac mass was composed of mildly anisocytotic spindle-shaped and stellate neoplastic cells with a small amount of cytoplasm and small, hyperchromatic nuclei that displayed only mild anisokaryosis. No mitoses were observed (Figure 2a). The neoplastic cells were embedded in an abundant extracellular matrix that was weakly PAS-positive and mildly metachromatic with toluidine blue (Figure 2b). Furthermore, small multifocal haemorrhages, numerous macrophages containing hemosiderin, and a single small group of neutrophilic granulocytes and plasma cells were 

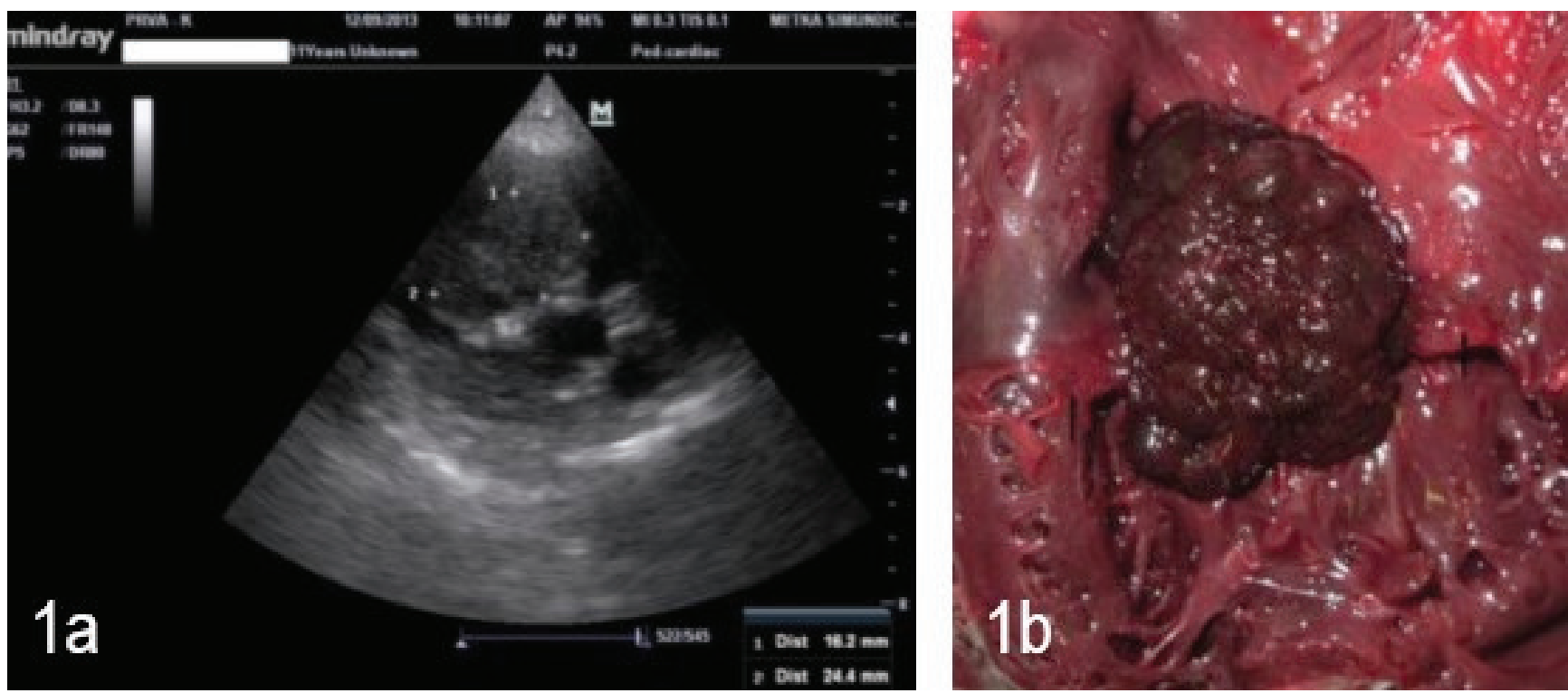

Figure 1: Pictures of cardiac myxoma. (1a) Homogenous isoechogenic intracavitary mass in the right ventricle and atrium was observed with two-dimensional echocardiography. (1b) Polypoid mass measuring 3 x $2.5 \times 1.5 \mathrm{~cm}$ was found arising from the parietal cusp of the tricuspid valve. The cusps of the tricuspid valve are marked with arrows
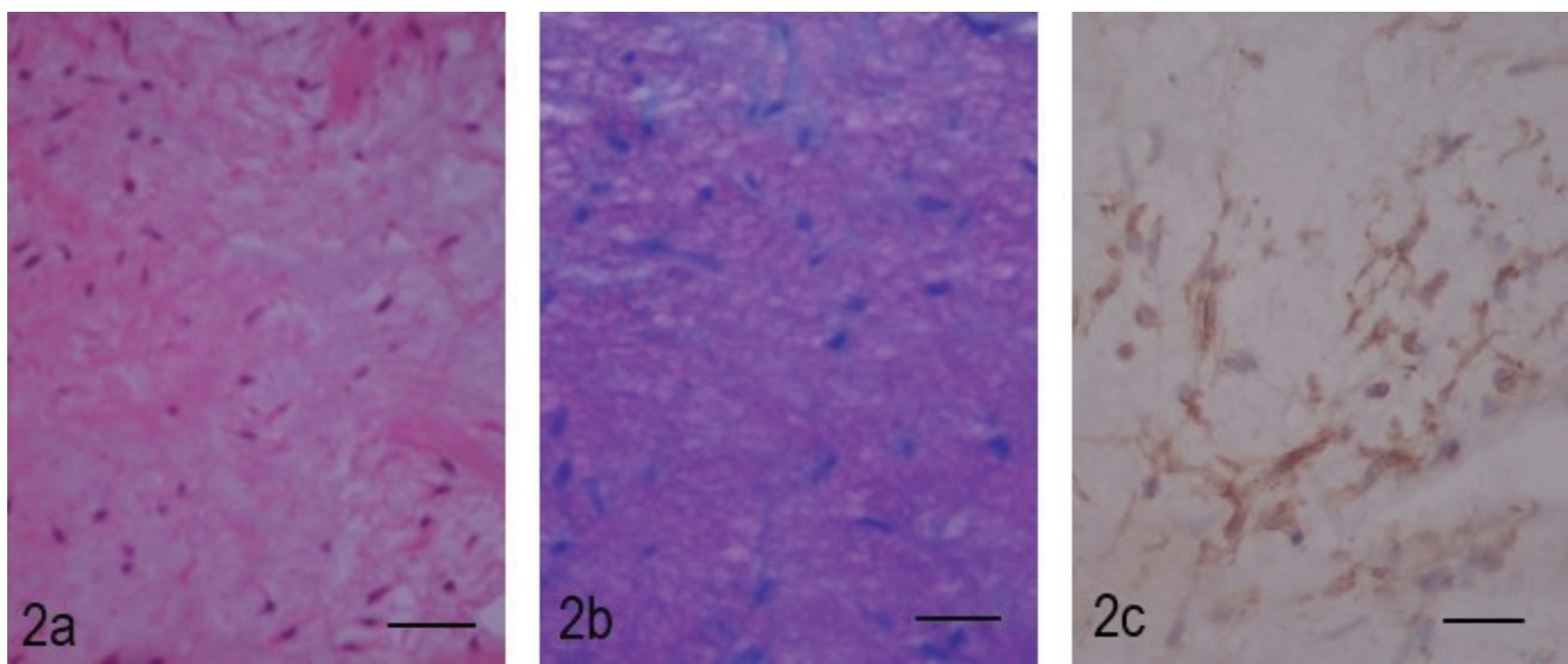

Figure 2: Pictures of cardiac myxoma. (2a) The neoplastic mass was composed of mildly anisocytotic spindleshaped and stellate neoplastic cells with a small amount of cytoplasm and small, hyperchromatic nuclei that showed only mild anisokaryosis. HE scale bare length $100 \mu \mathrm{m}$. (2b) The neoplastic cells are embedded in an abundant extracellular matrix that is metachromatically stained with Toluidine blue. Toluidine blue staining, scale bare length $100 \mu \mathrm{m}$. (2c) Immunostaining for vimentin shows strong positively expressed vimentin. Mouse monoclonal anti-vimentin antibody, horseradish peroxidase-labelled polymer (EnVision + Kit), counterstained with Mayer's haematoxylin, scale bare length $100 \mu \mathrm{m}$

found in the tumour. Immunohistochemically, the neoplastic cells were strongly positive for vimentin (Figure 2c).

Based on gross, microscopic, and immunohistochemical staining features, the neoplasm was diagnosed as cardiac myxoma.

\section{Discussion}

Cardiac myxoma is a very rare tumour in dogs, and to the authors knowledge, only seven cases have been reported so far $(8,9,10,11,12,13$, 14). As reported in the literature, myxoma is a 
tumour that occurs in relatively older dogs $(8-13$ years). It is significant to note that our patient, which was an older female dog with a tumour in the right heart, is in accordance with the reported data. In humans, the occurrence of myxoma has a clear gender predisposition since approximately $70 \%$ of affected cases are females (27). Although reports in the current peer-reviewed veterinary literature show that myxoma is a tumour with no gender predisposition, we found that in all reports, myxoma was found in the right heart of female dogs, whereas in male dogs, the left heart was affected.

Clinical presentation in dogs with cardiac tumours depends on the tumour's anatomic localization, size, effects on the haemodynamic properties, as well as the mobility of the mass. Most common cardiac tumours cause pericardial effusion leading to ascites, exercise intolerance and syncope, but they also can cause arrhythmias, pulmonary congestion and sudden death (14). Reported clinical signs of myxoma in the right part of the heart include congestion of systemic circulation, ascites and arrhythmias. In some reports, tumour emboli in the pulmonary arteries and, consequently, respiratory distress were found $(8,9,11)$. In the presented case, syncope was the only presenting problem. During the physical examination, ascites, presumably due to the right heart failure, and loud systolic/diastolic heart murmur were also found. However, the intensity and dynamics of the heart murmur could point toward a high level disruption of the laminary flow, presumably due to a huge intracardiac mass in this case. The presence of a heart murmur in canine cardiac myxoma is not a consistent finding because it is only reported in four of all reported cases. The common finding in these four cases is a high intensity (grade IV-V / VI) murmur of either a systolic or pansystolic duration $(8,10,11,13)$.

Syncope and cardiac murmur are very unspecific clinical signs and are common findings in canine patients with various cardiac and noncardiac diseases. Therefore, these symptoms can be easily misinterpreted.

In human medicine, transthoracic or transoesophageal ultrasonography (28), CT and/ or MRI scans can be used for the characterization of cardiac masses $(29,30)$ since differential diagnoses include thrombus and valvular diseases such as degeneration or vegetation. Due to the widespread accessibility of echocardiography, the diagnosis of cardiac tumours is becoming more frequent in veterinary medicine (31). In the presented case, transthoracic two-dimensional echocardiography was essential for the confirmation of the diagnosis; it revealed a mass arising from the tricuspid valve and filling the right atrium and ventricle, which is a common location for myxoma in canines. Namely, in two of seven reported cases of canine cardiac myxoma, the tumour originated in the left heart. Specifically, myxoma was found arising from the interventricular septum and obstructing the aorta in one case (14) and affecting posterior papillary muscle and the chordae tendineae of the mitral valve and left ventricle in the other case (13). In one of the other five cases, the tumour originated from the pulmonary valve and impaired the right ventricular outflow (10); the remaining four tumours originated from the tricuspid valve $(8,9$, $11,12)$. On the other hand, in humans, $60-86 \%$ of cardiac myxoma originate from the left atrium, $15-28 \%$ from the right atrium, and $8 \%$ from the right ventricle; furthermore, $1.6-8.5 \%$ of cardiac myxoma are biatrial and $1.6 \%$ are multifocal (35).

Canine cardiac myxoma haematological and biochemical results were only presented in four reports. In two of these reports $(10,13)$, the blood work was unremarkable. Specifically, moderate anaemia with mild neutrophilia was found in one case (9), while significantly elevated activity of ALT with borderline elevation of alkaline phosphatase was reported in the other case (11). Contrary to these reports, polycythaemia was the hallmark of blood work alterations in our case. It can be explained by impaired blood inflow to the right heart and, consequently, decreased blood flow through the lungs. This results in the decreased oxygenation of blood, which leads to a compensatory increased production of erythrocytes. Therefore, this alteration is probably a consequence of chronic hypoxia, since there are no data regarding the possible production of erythropoietin in cardiac myxoma leading to polycythemia, which is otherwise a well-known paraneoplastic syndrome in hepatic, renal and adrenal tumours (32). Similar to results reported by Machida et al (2003), elevated serum ALT activity was found, albeit the elevation in our case was only marginal. This elevation was probably caused by hepatic congestion induced from rightside heart failure (33).

Currently, surgery has been the treatment option for cardiac myxoma in humans (34) and 
veterinary medicine in which only two such cases were reported in dogs. One of these cases resulted in a very successful outcome and twoyear survival time (35). In the other case, however, the patient died 36 hours after surgical removal of the tumour (11).

\section{Conclusion}

Intracardiac tumours are very uncommon occurrences in dogs. However, they can be a rare aetiologic factor for syncope, arrhythmia and ascites, and therefore cardiac myoma should be included in the list of differential diagnosis in a case of listed clinical signs. Echocardiographic examination is essential for the clinical diagnosis of intracardial tumours, but the final diagnosis can only be made with histopathology.

\section{References}

1. Ware WA, Hopper D. Cardiac tumors in dogs: 1982-1995. J Vet Intern Med 1999; 13: 95-103.

2. Arruda MV, Braile DM, Joaquim MR, Soares MJ, Alves RH. Resection of left ventricular myxoma after embolic stroke. Rev Bras Cir Cardiovasc 2008; 23: 578-80.

3. Szczech GM, Blevins WE, Carlton WW, Cutlan GR. Chemodectoma with metastasis to bone in a dog. J Am Vet Med Assoc 1973, 162: 376-8.

4. Walter JH, Rudolph R. Systemic, metastatic, eu- and heterotope tumours of the heart in necropsied dogs. Zbl Vet Med A 1996; 43 :31-45.

5. Aupperle H, März I, Ellenberger C, Buschatz S, Reischauer A, Schoon HA. Primary and secondary heart tumours in dogs and cats. J Comp Pathol 2007; 31: 18-26.

6. MacGregor JM, Faria ML, Moore AS, Tobias AH, Brown DJ, de Morais, HS. Cardiac lymphoma and pericardial effusion in dogs: 12 cases (19942004). J Am Vet Med Assoc 2005; 227: 1449-53.

7. Di Palma S, Lombard C, Kappeler A, Posthaus H, Miclard J. Intracardiac ectopic thyroid adenoma in a dog. Vet Rec 2010; 167: 709-10.

8. Roberts SR. Myxoma of the heart in a dog. J Am Vet Med Assoc 1959; 134: 185-8.

9. Darke PG, Gordon LR. Cardiac myxoma in a dog. Vet Rec 1974; 21: 565-7.

10. Bright JM, Toal RL, Blackford LM. Right ventricular outflow obstruction caused by primary cardiac neoplasia. J Vet Intern Med 1990; 4: 121-6.

11. Machida N, Hoshi K, Kobayashi M, Katsuda $\mathrm{S}$, Yamane Y. Cardiac myxoma of the tricuspid valve in a dog. J Comp Pathol 2003; 30: 320-4.

12. Akkoc A, Ozyigit MO, Cangul IT. Valvular cardiac myxoma in a dog. J Vet Med A Physiol Pathol Clin Med 2007; 54: 356-8.

13. Fernandez-del Palacio MJ, Sanchez J, Talavera J, Martínez C. Left ventricular inflow tract obstruction secondary to a myxoma in a dog. J Am Anim Hosp Assoc 2011; 47: 217-23.

14. Nijs MI, Vink A, Bergmann W, Szatmári V. Left ventricular cardiac myxoma and sudden death in a dog. Acta Vet Scand 2016; 58: e41 (1-4). DOI 10.1186/s13028-016-0222-7

15. Gallay J, Belanger MC, Helie P, Cote E, Johnson TO, Peters ME. Cardiac leiomyoma associated with advanced atrioventricular block in a young dog. J Vet Cardiol 2011; 13: 71-7.

16. Fews D, Scase TJ, Battersby IA. Leiomyosarcoma of the pericardium, with epicardial metastases and peripheral eosinophilia in a dog. J Comp Pathol 2008; 138: 224-8.

17. Lombard CW, Goldschmidt MH. Primary fibroma in the right atrium of a dog. J Small Anim Pract 1980; 21: 439-48.

18. Speltz MC, Manivel JC, Tobias AH, Hayden DW. Primary cardiac fibrosarcoma with pulmonary metastasis in a Labrador Retriever. Vet Pathol 2007; 44: 403-7.

19. Mansfield CS, Callanan JJ, McAllister H. Intra-atrial rhabdomyoma causing chylopericardium and right-sided congestive heart failure in a dog. Vet Rec 2000; 147: 264-7.

20. 20. Krotje LJ, Ware WA, Niyo Y. Intracardiac rhabdomyosarcoma in a dog. J Am Vet Med Assoc 1990; 197: 368-71.

21. Foale RD, White RA, Harley R, Herrtage ME. Left ventricular myxosarcoma in a dog. $\mathrm{J}$ Small Anim Pract 2003; 44: 503-7.

22. 22. Sato T, Koie H, Shibuya H, Suzuki K. Extraskeletal osteosarcoma in the pericardium of a dog. Vet Rec 2004; 155: 780-1.

23. Wohlsein P, Cichowski S, Baumgartner W. Primary endocardial malignant spindle-cell sarcoma in the right atrium of a dog resembling a malignant peripheral nerve sheath tumour. J Comp Pathol 2005; 132: 340-5.

24. Cociancich V, Gombač M, Švara T, Pogačnik M. Malignant mesenchymoma of the aortic valve in a dog. Slov Vet Res 2013; 50: 83-8. 
25. Di Vito A, Mignogna C, Donato G. The mysterious pathways of cardiac myxomas: a review of histogenesis, pathogenesis and pathology. Histopathology 2015; 66: 321-32.

26. Amano J, Nakayama J, Yoshimura Y, Ikeda U. Clinical classification of cardiovascular tumors and tumor-like lesions, and its incidences. Gen Thorac Cardiovasc Surg 2013; 61: 435-47.

27. Jang KH, Shin DH, Lee C, Jang JK, Cheong S, Yoo SY. Left atrial mass with stalk: thrombus or myxoma? J Cardiovasc Ultrasound 2010; 18: 154-6.

28. Saito Y, Aizawa Y, Monno K, et al. Small, smooth, nonmobile cardiac myxoma detected by transesophageal echocardiography following recurrent cerebral infarction: a case report. J Med Case Rep 2017; 11: e131 (1-5). https://doi. org/10.1186/s 13256-017-1298-z

29. Keeling IM, Oberwalder P, Anelli-Monti M, et al. Cardiac myxomas: 24 years of experience in 49 patients. Eur J Cardiothorac Surg 2002; 22: 971-7.

30. Hoey ETD, Mankad K, Puppala S, Gopalan D, Sivananthan MU. MRI and CT appearances of cardiac tumours in adults. Clin Radiol 2009; 64: 1214-30.

31. Bussadori CB, Quintavalla C, Pradelli, D, Marconato L. Diagnostic imaging for the identification of cardiac tumours in humans and dogs. In: Proceedings of the 13th Ljudevit Jurak International Symposium on Comparative Pathology Zagreb. Acta Clin Croat 2002; 41: 155.

32. Bergman, P. Paraneoplastic syndromes. In: Vail DM, Withrow SJ, Page RL, eds. MacEwen's small animal clinical oncology. St. Louis, Missouri : Saunders, 2013: 83-97.

33. Alvarez AM, Mukherjee D. Liver abnormalities in cardiac diseases and heart failure. Int J Angiol 2011; 20: 135-42.

34. Zhang RD, Zeng $\mathrm{ZH}$, Zheng JY, et al. Left atrial myxoma complicated with multi-system embolization. J Card Surg 2017; 12: e76 (1-5). https://doi.org/10.1186/s13019-017-0640-2

35. Barh, D, Kumar A, Chatterjee S, Liloglou T. Molecular features, markers, drug targets, and prospective targeted therapeutics in cardiac myxoma. Curr Cancer Drug Targets 2009; 7: 779816.

\title{
MIKSOM SRCA PRI PSU
}

\author{
M. Šimundić, A. Domanjko Petrič, D. Pavlin, T. Zemljič, I. Firm, M. Gombač, Š. Srečnik, M. Stojov, L. Šimenc, T. Švara
}

Povzetek: Tumorji srca so pri živalih in ljudeh redki. Pri psih se v srcu najbolj pogosto pojavljata hemangiosarkom in kemodektom, pojavnost miksomov pa je izjemno nizka. $\vee$ prispevku predstavljamo primer miksoma triksupidalne zaklopke pri psički mešanki, stari 11 let. Psička je prišla na pregled zaradi enkratne sinkope in ker je bila bolj mirna in utrujena. Ugotovili smo tahikardijo, tahipnejo in progresivni ascites. Z dvodimenzionalno ultrazvočno preiskavo smo v desnem delu srca ugotovili polipoidno intrakavitarno maso. Pri raztelesbi smo ugotovili, da je polipoidna, temno rdeča novotvorba izraščala iz parietalnega lista triksupidalne zaklopke. Mikroskopsko je bila novotvorba zgrajena iz vretenastih in zvezdastih celic, z majhnimi, hiperkromatičnimi jedri, ki jih je obdajal miksoidni matriks. Zimunohistokemičnim barvanjem smo potrdili, da so novotvorbne celice izražale vimentin. Novotvorbo smo na osnovi makroskopskih in mikroskopskih značilnosti diagnosticirali kot miksom srca.

Ključne besede: miksom; srce; pes; dvodimenzionalna ultrazvočna preiskava; histopatologija; imunohistokemija 